\title{
Porcine Coccidiosis: Prevalence Study in Ganye Southeasthern Admawa State, Nigeria
}

\author{
Tsunda, B.M, Ijasini, S.B and Jamala, G.Y \\ Adamawa State College of Agriculture, Ganye
}

\begin{abstract}
The study of the prevalence of porcine coccidiosis in Ganye Local Government Area Adamawa State indicate that Eimeria perminuta, Eimeria Scabra, Isospora Suis, Eimeria Spinosa, Eimeria debliecki ,Eimeria Polita and Eimeria Porci were the commonest Coccidian Oocysts encountered with prevalence rates of $63.9 \%, 21.3 \%, 10.6 \%, 12.8 \%, 4.3 \%, 4.3 \%$ and $6.4 \%$ respectively. However, the prevalence of Eimeria perminuta was significantly more $(p<0.05)$ compared to all other species encountered in the study area.Of the 130 pigs examined a prevalence of $36.2 \%$ was recorded. Female pigs also had a significantly higher rate of infection $(p<0.05)(57.5 \%)$ compared to the male pigs $(42.6 \%)$. Also young pigs were significantly higher $(p<0.05)$ in August (50\%) as compared to the months of September and October with prevalence rate of $33.3 \%$ and $26.7 \%$. Eimeria Scabra was the largest oocysts with the size of $32.0 \times 22.0 \mathrm{~nm}$, while the smallest oocyst was that of Eimeria perminuta with $13.5 \times 11.5 \mathrm{~nm}$.
\end{abstract}

Keywords: Porcine coccidiosis, Prevalence, Disease, Specie, Season, Infection

\section{Introduction}

Porcine coccidiosis is caused by small parasites that multiply inside the host cell mainly in the intestinal tract. There are three types, Eimeria isospora and Crytosporidia soulsby (1982). The disease coccidiosis is common and wide spread in suckling piglets but is seen occasionally in growing and finishing pigs and Boars when they are moved or housed into continually populated and infected pens.

Coccidiosis is usually suspected when there is diarrhea problem in suckling pigs from 7-21 days of age that does not respond particularly well to antibiotic. Diarrhea is the main clinical sign in early stages, in later stages the feces vary in consistency and colour from yellow to grey green or bloody according to the severity of the condition. Dehydration is common, wasting, poor growth, sloppy diarrhea may be seen, and feces /diarrhea may occasionally be tinge with blood (Ruprah, 1985). Soulsby (1982), and other authors Ruprah (1985) and Urquhart et al. (1992) maintained that several species of Eimeria are responsible for the prevalence of porcine coccidiosis and these includes: Eimeria debliecki, Eimeria suis, Eimeria perminuta, Eimeria scabra, Eimeria spinosa, Eimeria cerdonie, Eimeria neodebliecki, Eimeria porci, and Isosporasuis.

The coccidian ocysts are passed in feces and though may not cause a significant mortality but can certainly cause a clinical disease or can at least retard the growth of pigs (Davies et, al.1963, Ruprah, 1985). Porcine coccidiosis is much more common in young animals than in adults and outbreaks of coccidiosis may occur in 45 months old pigs (Ruprah, 1985). Therefore, this study was carried out to examine the prevalence of porcine coccidiosis in Pigs found in Ganye, Adamawa State, Nigeria

\section{Materials and Methods}

The Study Area

The study was carried out in Ganye Local Government area, located in the Southeastern part of Adamawa State (Longitude $12^{\circ} \mathrm{N}$, Latitude $09^{\circ} \mathrm{E}$ ). It is bounded by Jada to the North, Mayo-Belwa and Taraba State to the West, Toungo to the South and to the East Cameroon Republic (Adebayo, 1999). It has a land mass of $2291.42 \mathrm{~km}^{2}$ and a population of 164,087 (NPC, 2007). The mean annual temperature of the study area is $26.7^{\circ} \mathrm{C}$ and the mean annual rainfall ranges between $1000 \mathrm{~mm}$ and $1600 \mathrm{~mm}$ with a distinct dry season which begins in November, and ends April and the wet season begins in April and ends in October or sometimes in November. The area is located within the Guinea Savannah Zone of the Nigeria's vegetation Zones (Adebayo 1999). The major economic activity in the area is agriculture, food crops grown in the area includes Maize, sorghum, cowpea, Cassava and Potatoes. While Cash crops such as Ground nuts, Rice, Yam and Sugarcane are produced in large quantities. The famers are also engaged in collection and processing of non-timber forest such as Shea nuts. Major livestock reared in the Zones are cattle, sheep, Pigs and goats (Ad seeds, 2004).

\section{Sample Collection}

Fecal sample were collected within Ganye Local Government Area from slaughtered domestic pigs into a clean sterile and dry in universal bottle, between August and, October. A total no of 130 samples were examined, pigs within the age range of 9-12 months were considered young, 1year and above as adults pigs. 


\section{Sample Examination}

Fecal samples collected and observed using the simple floatation method by use of saturated salt solution of sodium chloride ( $\mathrm{NaCl}$ ), as described by Sloss and Kemp, (1978). 5grams of feces was placed in a universal bottle and $15 \mathrm{ml}$ of water added, the suspended particles filtered and sieve. The filtrate was subjected to centrifugation at 3000rpm for about $10-15$ minutes.

The supernatant was decanted and the deposit re-suspended in $5 \mathrm{mls}$ of saturated salt solution, the universal bottle was topped to the brim and a clean degreased slide placed over the mouth of the test tube and was allowed to stand for 10-15 minutes. After the desired time was reached the glass slide removed swiftly turn over and cover with the cover slip and the slide observed under the microscope using X10 objectives for clear view . Sample proved to be positive were washed and the Oocyts concentrated by centrifugation at 3000rpm which was then sporulated in $2.5 \%$ potassium solution in a Petri dish at temperature of $27-29^{\circ} \mathrm{C}$ (Levine, 1985). Time of sporulation for each Oocyts was recorded.

Details on the morphology including colour, presence or absence of micropyle, shape, Length and breath as well as thickness of the walls of Oocyts were recorded following observations under the light microscope using X40 objective lens. Hammond and Long,(1973).Size of the Oocyts were measured by the use of whipple disc using X40 objective lens and reading converted to micrometer(um).The species were identified based on the description of soulsby (1982) and Urquhart et al, (1992).Also details on the prevalence of infection rate based on the sex, sand age of the pigs were analyzed using the student test with $\mathrm{P}<0.05$ considered significant (Comppell,1985).

\section{Results and Discussion}

The results of the study indicates that Eimeria perminuta, Eimeria scabra, Isospora suis, Eimeria spinosa, Eimeria debliecki ,Eimeria polita and Eimeria porci were the commonest Coccidian Oocysts encountered with prevalence rates of $63.9 \%, 21.3 \%, 10.6 \%, 12.8 \%, 4.3 \%, 4.3 \%$ and $6.4 \%$ respectively (Table 1). However, the prevalence of Eimeria perminuta was significantly high $(\mathrm{p}<0.05)$ compared to all other species encountered in the study The 130 pigs examined a prevalence of $36.2 \%$ was recorded (Table 2). Female pigs also had a significantly higher rate of infection $(\mathrm{p}<0.05)(57.5 \%)$ compared to the male pigs $(42.6 \%)$. Also young pigs were significantly higher $(\mathrm{p}<0.05)$ in August $(50 \%)$ as compared to the months of September and October with prevalence rate of $33.3 \%$ and $26.7 \%$ respectively. Table II shows the details on the morphology and morphometry and the Locusts identified during the study. Eimeria scabra was the largest locusts with the size of $32.0 \times 22.0 \mathrm{~nm}$, while the smallest ocysts was that of Eimeria perminuta with $13.5 \times 11.5 \mathrm{~nm}$, Table 3 also shows Eimeria spinosa possess the longest sporulation time (16 days) while Isospora suis had the shortest sporulation time of 4 days.

The study has revealed that porcine coccidiosis is common in the arid zone of Nigeria though of a fairly low occurrence (36.2\%). The species encountered during this study have also been confirmed by other workers (Soulsby, 1982, Ruprah, 1985 and Urquhart et. al, 1992) as the commonest worldwide disease. Noller and Frenz, (1922), Swason and Kates, (1940), O’Neil and Parfitt (1976) and Ruprah (1985) reported that Coccidial infection are mostly seen in young piglets (4-5 months) and piglets reared in infected herds are usually resistant to natural infection for the first three weeks of life but are susceptible thereafter and that older pigs are carriers. This confirms the findings of this study, however the finding of a significantly higher infection among female compared to male counterparts though unexplained by previous workers may be attributed to cyclical changes which can be immune-suppressive. This study has revealed that infections are more common in August and this agrees with the reports by Lee and Armour (1959) and Current et al., (1984) that most cases of coccidiosis occur between August and September due to change of environmental factors such as humidity, rainfall, temperature and climate. To adequately control Porcine coccidiosis and reduce losses due to morbidity and mortality it is pertinent that proper use of anti-coccidial drugs be made on piggeries in addition to an improved pig husbandry.

Table 1: Prevalence of coccidian parasite of pigs examined in Ganye

\begin{tabular}{ll}
\hline Coccidian species & No (\%) Infection \\
\hline Eimeria Perminuta & $30(63.9)$ \\
Eimeria Scabra & $10(21.3)$ \\
Isospora Suis & $5(10.6)$ \\
Eimeria Spinosa & $6(12.8)$ \\
Eimeria debliecki & $2(4.3)$ \\
Eimeria polita & $2(4.3)$ \\
Eimeria porci & $3(6.4)$ \\
TOTAL & 47 \\
\hline
\end{tabular}


Table 2: Prevalence of coccidian ocysts of pigs based on, age, sex of pigs, and month of study

\begin{tabular}{lll}
\hline & Total examined & No(\%)of total infection \\
\hline All pigs & 130 & $47(36.2)$ \\
Sex: & & \\
Female & 60 & $27(57.5)$ \\
Male & 70 & $20(42.6)$ \\
Age: & & $30(37.5)$ \\
Young & 80 & $17(34.0)$ \\
Adult & 50 & \\
Month & & $20(50)$ \\
August & 40 & $15(33.3)$ \\
September & 45 & $12(26.7)$ \\
\hline October & 45 & \\
\hline
\end{tabular}

Table 3: Morphological and morphometrical details of the various Coccidian ocysts Isolated from pigs

\begin{tabular}{|c|c|c|c|c|c|c|}
\hline Coccidian species & $\begin{array}{l}\text { Average } \\
\text { ocysts(lxb) } \\
\text { micrometre }\end{array}$ & $\begin{array}{r}\text { size } \\
\text { in }\end{array}$ & Sporulation time & Shape & Morphology & \\
\hline Eimeria scabra & $32.0 \times 22.0$ & & 10 & Ovoid & Rough & Absent \\
\hline Eimeria Perminuta & $13.5 \times 11.5$ & & 6 & Sub-spherical & Rough & Absent \\
\hline Eimeria polita & $26.0 \times 19.0$ & & 8 & Oval & Smooth yellowish & Absent \\
\hline Isospora suis & $22.5 \times 20.0$ & & 4 & Sub-spherical & Smooth colorless & Absent \\
\hline Eimeria debliecki & $25.0 \times 18.0$ & & 5 & Ellipsoidal & Smooth & present \\
\hline Eimeria spinosa & $19.5 \times 12.5$ & & 16 & Ovoid & Rough brown & Absent \\
\hline Eimeria porci & $19.5 \times 15.5$ & & 9 & Ovoid & Smooth & Absent \\
\hline
\end{tabular}

\section{Conclusion}

In conclusion from the present research carried out in Ganye, Porcine coccidiosis prevalence study in Ganye has shown that young pigs are more affected compared to the adults pigs and more cases are recorded in the month of August compared to the months of June and July. This indicate that the effects of the disease will have a negative impact on the society as this may give rise to poor meat quality and even death of the animals.

\section{References}

[1]. Andrews, J. S and Prindle, L. A. (1952). Eimeria spinosa record from swine raised in Mary land and Geogia plot. Helminthsoc. Wash, 19, 64 .

[2]. Anon. (1971). Mannual of Vet.parasitol.Lab.Tech.Technical bulletin No.18:64- 66.

[3]. Biester,H.E and Murray C,(1992). .J.Am.Veterinary Medicine Assoc.75,705.

[4]. Deom, J and Mortelmans, J. (1954). Observation Sua lar coccidios du pore Eimeriadebliecki en congo Belge. Ann. Soc. Belge med. Trop. 34, 43 .

[5]. Ernest, J. V and Lindsay, D. C. (1983). What to know about Coccidiosis. Hog farm management 20: 48-50.

[6]. Foster, A. O. (1949). The economic losses due to coccidiosis Ann. Ny Acad, Sci. 52, 434, 442.

[7]. Georgi, J. R. and Georgi, M. E. (1990). Parasitol for Veterinarians. $5^{\text {th }}$ edition.

[8]. Hammond, D. M. (1973) Lifecycle and dev. of Coccidiosis. In Hammond D.M. and Long,P.1(eds): The coccidian Baltimore, Maryland University, park press pp.45-79

[9]. Levine, N. D. (1985). Vet.Protozoology. The Iowa state University press.p.163-164. Lindsay, D. S. and Current, W.L (1984) Prevalence of oocysts of Isospora suis and Eimeria spp from sows on farms with and without history of neonatal Coccidiosis.J.Am.Vet.Med.Assoc.185:419-421.

[10]. Noller and Frenz (1922). Dent. Tieraztt Wchnschr 1, 301.

[11]. Oneil, P. A and Perfitt, J. W. (1976). Observation of Isospora suis infection in minimal disease of pigs herd .Vet, research $98,321,323$.

[12]. Rommel, M. (1970). Studies on the nature of overcrowding effect on the immunity to coccidiosis J. Parasitol.5:468.

[13]. Rose, M. E. (1970). Immunity in Hammond, D. M. and Long, P. L. (eds): The Coccidian. Baltimaire Maryland University park press Pp295-341.

[14]. Ruprah, N. S. (1985). Atattriok of clinical Protozoology. Oxonnian press P V T. Ltd. New Delhi.

[15]. Rommel and Pczynski (1967). .Der.Lebenszykulns des schwemakokzids. Eimeria scabra.Henry, (1931). Barl. Munch.

[16]. Swason, L. E. and Kates, K. C. (1940). Coccidiosisin litter Pigs. Proc. Helminth Soc. Wash. 7, $29,30$.

[17]. Stuart, B. P, S. K, D. B, Bentel, D. M (1982). Demonstration of immunity against Isospora suis in Swine. Vet. Parasitol, pp 185191.

[18]. Soulsby, E. J. L (1982). Helminthes, Arthropods and Protozoan of domesticated animals. $7^{\text {th }}$ edition Pp.593-614.Bailliere Tindall, London.

[19]. Tyzzer, E.E. (1929). Coccidiosis in gallinaeus birds. AM.J. Ayg, 10:265-383.

[20]. Urquhart, G. M, Armour, J. Duncan, J. R. Dun, N, A. M and Jennings. F. W (1992).Veterinary Parasitology. Longman group U.K. ltd.

[21]. Vetterling, J. M (1965). Coccidian protozoa. Eimeridae of Swine J. Parasitology, 5:897-912.

[22]. Wiensenhutter, E. (1962). Experimental Studien ubar die Entwicklung von Eimeria debliecki and Eimeria spinosa de schweins. Inang DISS, Berlin. 